MaPan : Jurnal Matematika dan Pembelajaran

p-ISSN: 2354-6883 ; e-ISSN: 2581-172X

Volume 7, No 2, December 2019 (249-260)

DOI: https://doi.org/10.24252/mapan.2019v7n2a6

\title{
MODEL REPRESENTASI MATEMATIS SISWA KELAS IV DALAM MENYELESAIKAN SOAL CERITA
}

\author{
Suci Yuniati1), Suparjono ${ }^{2}$ \\ 1,2Universitas Islam Negeri Suska Riau \\ 1,2Jalan. Hr Subrantas No. 155 Pekanbaru-Riau \\ E-mail: suci.yuniati@uin-suska.ac.id ${ }^{1}$, suparjono@uin-suska.ac.id²)
}

Submitted: 21-03-2019, Revised: 26-07-2019, Accepted: 21-11-2019

\begin{abstract}
Abstrak:
Penelitian ini bertujuan untuk menyelidiki model representasi siswa kelas IV dalam menyelesaikan soal cerita. Representasi merupakan cara yang digunakan siswa untuk menemukan solusi dan mengemukakan ide atau gagasan dari suatu masalah yang sedang dihadapi. Soal cerita digunakan untuk menyelidiki model representasi yang digunakan siswa dalam menyelesaikan permasalahan. Hasil penelitian menunjukkan bahwa siswa lebih memilih representasi numerik dalam proses penyelesaian soal cerita, dikarenakan siswa kebanyakan menggunakan angka. Representasi siswa dalam menyelesaikan soal cerita masih belum maksimal karena hanya ada representasi numerik yang digunakan siswa maka seharusnya guru merencanakan pembelajaran dan memfasilitasi kegiatan dalam proses pembelajaran dengan memberikan latihan-latihan soal cerita sehingga siswa dapat terlatih dalam merepresentasikan penyelesaian soal cerita dengan representasi matematis yang lain dan dapat mengkombinasikannya dengan representasi matematis lainnya.
\end{abstract}

Kata Kunci: Representasi Matematis, Soal Cerita

\section{MATHEMATICAL REPRESENTATION MODEL OF THE FOURTH GRADE STUDENTS IN COMPLETING STORY PROBLEM EXERCISES}

\begin{abstract}
:
This research aimed to investigate the representation model of the 4th grade students in solving story problem exercises. Representation is a way that students use to find solutions and express thoughts or ideas of problem faced. The story problem was used to investigate the representation model used by the students in solving problems. The results of the study showed that the students preferred numerical representation in the process of solving story problems because of most of them used numbers. The representation of students in solving story problems were still nonoptimal because there were only numerical representations used by students. Therefore, the teacher should plan learning and facilitate activities in the learning process by providing storytelling exercises so that the students could be trained in representing the completion of story problems with other mathematical representations and could combine it with other mathematical representations.
\end{abstract}

Keywords: Mathematical Representation, Story Problems 
How to Cite: Yuniati, S., \& Suparjono. (2019). Model representasi matematis siswa kelas IV dalam menyelesaikan soal cerita. MaPan : Jurnal Matematika dan Pembelajaran, 7(2), 249-260.

\section{PENDAHULUAN}

$\mathrm{P}$ embelajaran matematika terdiri dari tiga komponen utama yaitu tujuan pembelajaran, proses pembelajaran, dan evaluasi. Ketiga unsur tersebut harus saling berkaitan dan saling menunjang dalam kegiatan pembelajaran. Langkah pertama yang dilakukan dalam kegiatan pembelajaran adalah membuat tujuan pembelajaran. Tujuan pembelajaran merupakan komponen utama yang harus ditetapkan dalam proses pembelajaran karena digunakan sebagai indikator keberhasilan pembelajaran. Guru harus menetapkan strategi pembelajaran yang cocok dengan tujuan pembelajaran yang telah dirumuskan dan perkembangan psikologis siswa. Langkah terakhir dalam pembelajaran matematika adalah evaluasi. Evaluasi berperan untuk melihat sampai sejauh mana tujuan pembelajaran sudah tercapai.

Tujuan pembelajaran akan tercapai apabila di dalam proses pembelajaran guru dapat membangun pengetahuan kemampuan matematis siswa. Menurut NCTM (2000), standar kemampuan matematis yang harus dimiliki oleh siswa yaitu kemampuan: (1) pemecahan masalah; (2) komunikasi; (3) penalaran; (4) koneksi; dan (5) representasi. Tiga hal yang harus dikuasai siswa terkait representasi yaitu: (1) mampu menciptakan, dan menggunakan representasi untuk mengorganisasi, merekam, dan mengomunikasikan ide; (2) memilih, menggunakan, dan mentranslasi berbagai representasi untuk menyelesaikan masalah; dan (3) menggunakan representasi untuk memodelkan dan menginterpretasikan suatu fenomena (NCTM, 2000). Hal ini menunjukkan bahwa kemampuan representasi merupakan salah satu aspek terpenting dalam pembelajaran matematika. Kemampuan representasi dapat membantu siswa dalam merencanakan dan menganalisis pemecahan masalah, sehingga menimbulkan kreativitas proses berpikir siswa dalam menyelesaikan masalah matematika.

Representasi merupakan cara yang digunakan siswa untuk menemukan solusi dan mengemukakan ide atau gagasan dari suatu masalah yang sedang dihadapi (Cai, Jakabcsin, \& Lane, 1996; Goldin, 2002; Jones \& Knuth, 1991; NCTM, 2000). Menurut Friedlander \& Tabach (2001), penggunaan representasi verbal, numerik, grafik, dan representasi aljabar memiliki potensi membuat proses belajar aljabar menjadi bermakna dan 
efektif yaitu: (1) representasi verbal biasanya digunakan dalam mengajukan masalah dan diperlukan dalam interpretasi akhir dari hasil yang diperoleh dalam proses penyelesaian. Presentasi masalah verbal menciptakan lingkungan alami untuk memahami konteks dan mengomunikasikan solusi. Penalaran verbal juga dapat menjadi alat untuk memecahkan masalah dan dapat memfasilitasi presentasi dan penerapan pola umum. Ini menekankan hubungan antara matematika dan domain lain dari akademik dan kehidupan sehari-hari; (2) representasi numerik merupakan representasi yang sudah akrab di tahap awal belajar aljabar siswa. Pendekatan numerik menawarkan kemudahan dan jembatan yang efektif pada aljabar dan sering mendahului setiap representasi lain. Penggunaan nomor/angka penting dalam memperoleh pemahaman pertama dari masalah dan menyelidiki kasus-kasus tertentu; (3) representasi grafik merupakan representasi yang efektif dalam memberikan gambaran yang jelas tentang nilai fungsi real dari variabel real. Grafik yang intuitif dan sangat menarik untuk siswa yang suka pendekatan visual; dan (4) representasi aljabar merupakan representasi yang ringkas, umum, dan efektif dalam presentasi pola dan model matematika. Manipulasi objek aljabar kadang-kadang satu-satunya metode dalam membenarkan atau membuktikan pernyataan umum.

Menurut Friedlander \& Tabach (2001), kelebihan penggunaan reprensentasi verbal, terdiri dari: representasi verbal kelebihannya adalah: (1) penalaran verbal dapat menjadi alat untuk memecahkan masalah dan dapat memfasilitasi presentasi dan penerapan pola umum; (2) dapat digunakan dalam mengajukan masalah dan diperlukan dalam interpretasi akhir dari hasil yang diperoleh dalam proses penyelesaian; (3) representasi verbal menciptakan lingkungan alami untuk memahami konteks dan untuk mengkomunikasikan solusi penyelesaian; dan (4) representasi verbal menghubungkan antara matematika dan domain lain dari akademik dengan kehidupan sehari-hari. Sementara itu, kelebihan representasi numerik yaitu: (1) representasi yang sering digunakan siswa pada tahap awal representasi aljabar; (2) menawarkan sebuah kemudahan dan jembatan yang efektif pada aljabar dan sering mendahului setiap representasi lain; dan (3) penggunaan nomor/angka penting dalam memperoleh pemahaman yang pertama dari masalah dan dalam menyelidiki kasus-kasus tertentu. Representasi grafik memiliki kelebihan yaitu: (1) representasi grafis efektif dalam memberikan gambaran yang jelas tentang nilai fungsi dari variabel real dan (2) grafik yang intuitif dan sangat menarik untuk siswa yang suka pendekatan visual. 
Representasi aljabar juga memiliki kelebihan yaitu: (1) ringkas dan efektif dalam presentasi pola dan model matematika dan (2) manipulasi objek aljabar merupakan satu-satunya metode dalam mewakili pernyataan umum.

Banyak penelitian yang menegaskan bahwa representasi dapat digunakan siswa dalam mengemukakan ide atau gagasan mereka dalam menyelesaikan masalah matematika (BAL, 2014; Delice \& Sevimli, 2010; Hwang, Chen, Dung, \& Yang, 2007; Mielicki \& Willey, 2016; Ozgun-Koca, 1998; Surya, Sabandar, Kusumah, \& Darhim., 2013). Misalnya, BAL (2014) menunjukan bahwa siswa menggunakan berbagai representasi untuk menyelesaikan masalah yang diberikan. Hasil penelitian BAL (2014) menyatakan bahwa representasi yang paling banyak digunakan adalah representasi verbal. Pada tahap perencanaan, representasi yang digunakan adalah representasi aljabar. Tahap memahami masalah, representasi yang paling banyak digunakan adalah representasi verbal dan grafik. Pada tahap merencanakan penyelesaian, representasi yang banyak digunakan adalah representasi verbal dibandingkan representasi grafik dan aljabar. Menurut Mielicki \& Willey (2016), siswa lebih berhasil menyelesaikan masalah menggunakan representasi grafik dibandingkan menggunakan representasi simbolik. Berdasarkan beberapa penelitian di atas, maka peneliti ingin melihat model representasi yang digunakan siswa SD dalam menyelesaikan soal cerita.

Soal cerita merupakan soal yang dibuatkan dalam bentuk cerita pendek atau rangkaian kalimat sederhana dan bermakna yang terkait dengan kehidupan sehari-hari (Chilmiyah, 2014). Hal yang perlu diperhatikan dalam menyelesaikan soal cerita yang adalah proses penyelesaiannya bukan hasil akhir dari jawaban siswa dan ketika menyelesaikan soal cerita diharapkan siswa mengerjakan secara bertahap sehingga terlihat proses berpikir siswa. Keterampilan yang perlu dimiliki siswa dalam memecahkan soal cerita yaitu kemampuan memahami masalah, menerapkan metode resolusi yang tepat, dan membangun model abstrak (Gerjets, Scheiter, \& Catrambone, 2004; Koedinger \& Nathan, 2004; Scheiter, Gerjets, \& Schuh, 2010). Menurut Tambunan (1999), kemampuan siswa dalam menyelesaikan soal cerita merupakan keterampilan dan kreativitas yang dimiliki siswa. Keterampilan dan kreativitas siswa dalam penyelesaian soal cerita merupakan macammacam representasi siswa. Dengan demikian, dalam tulisan ini bertujuan untuk menyelidiki model representasi yang digunakan siswa dalam menyelesaikan soal cerita. 


\section{METODE PENELITIAN}

Jenis penelitian yang digunakan dalam penelitian ini adalah penelitian kualitatif yang bersifat deskriptif. Penelitian ini mendeskripsikan model representasi siswa dalam penyelesaian soal cerita. Subjek dalam penelitian ini adalah siswa kelas IV sekolah Sekolah Dasar (SD) yang berjumlah 26 siswa. Sekolah tersebut dipilih sebagai sampel penelitian karena memiliki indikasi bahwa siswa memiliki beberapa representasi dalam menyelesaikan soal cerita. Sekolah tersebut terletak di pinggiran Kabupaten Malang. Berdasarkan informasi dari guru kelas IV, siswa tersebut memiliki kemampuan matematika rata-rata menengah dan sudah mendapatkan pengajaran tentang materi operasi pengurangan bilangan cacah. Hasil pekerjaan semua subjek diidentifikasi representasi yang digunakan siswa dalam menyelesaikan soal cerita.

Instrumen yang digunakan dalam penelitian ini adalah tes dan wawancara. Tes yang diberikan berbentuk soal uraian. Wawancara dilakukan dengan wawancara tidak terstruktur. Tes diberikan kepada semua siswa yang berjumlah 26 orang dan waktu yang digunakan dalam menyelesaikan tes adalah 20 menit. Bentuk soal yang digunakan adalah soal yang disusun berdasarkan suatu kasus atau kejadian untuk mengeksplor siswa dalam menggunakan representasi. Tingkat kesulitan soal yang diberikan termasuk tipe "soal sedang" dengan tujuan agar siswa dapat mengeksplor kemampuannya dalam menyelesaikan saol cerita.

Analisis yang dilakukan yaitu membandingkan hasil wawancara dan hasil lembar jawaban siswa. Dengan demikian, teknik analisis data menggunakan triangulasi metode. Berdasarkan hasil analisis peneliti mengklasifikasikan beberapa representasi digunakan dan karakteristik jawaban siswa. Pengklasifikasian tersebut terdiri dari 3 kategori dan setiap kategori diambil 1 siswa, sehingga diperoleh 3 subyek penelitian.

\section{HASIL PENELITIAN DAN PEMBAHASAN}

Dari 26 siswa yang diberikan soal cerita, hampir semua siswa yang mengunakan representasi numerik tetapi memiliki karakteristik jawaban yang berbeda. Berikut ini adalah hasil penelitian dari 3 subjek yang diklasifikasikan berdasarkan karakteristik jawaban subjek penelitian. Soal cerita yang diberikan ke siswa dapat dilihat pada gambar 1 . 
Ayahku memiliki 500 ekor kambing. Setelah diberi makan temyata kambing ayahku keracunan dan mati 469 ekor. Sisa berapakah kambing ayahku?

Gambar 1. Soal cerita yang Diberikan kepada Siswa

Deskripsi hasil pekerjaan subjek (S1) dapat dilihat pada gambar 2 dan gambar 3 berikut ini.

Cara pertama:

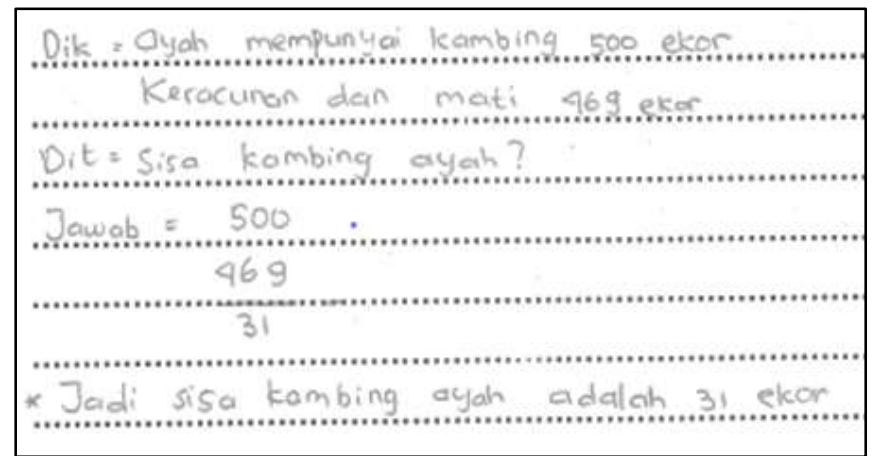

Gambar 2. Hasil Pekerjaan Subjek (S1) pada Cara Pertama

Dari gambar 2, jawaban yang diperoleh S1 "benar". Wawancara yang dilakukan pada subjek S1 menunjukan bahwa S1 memahami masalah yang diberikan. Dalam proses penyelesaian S1 mengunakan representasi numerik yaitu menggunakan nomor/angka dan S1 memilih cara penyelesaian dengan cara "bersusun". Banyaknya kambing 500 ekor, kemudian menghubungkan dengan banyaknya kambing 469 ekor yang mati dengan operasi pengurangan.

Cara kedua:

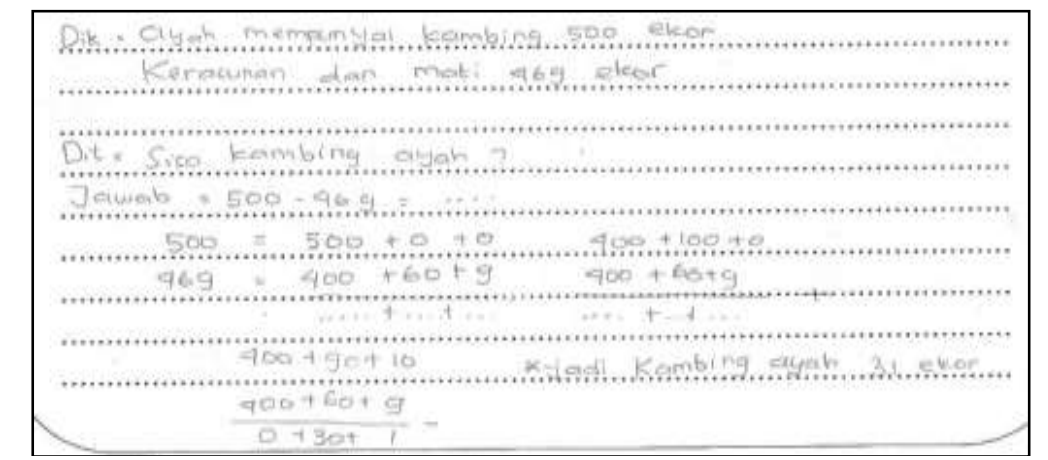

Gambar 3. Hasil Pekerjaan Subjek (S1) pada Cara Kedua 
Cara kedua yang dilakukan subyek (S1) yaitu menggunakan representasi numerik dengan cara menghubungkan banyaknya kambing 500 ekor dengan banyaknya kambing 469 ekor yang mati dengan operasi pengurangan. Namun cara yang digunakan S1 dengan menguraikan bilangan ratusan, puluhan, dan satuan lalu dikurangkan. Lihat gambar 3.

Deskripsi hasil pekerjaan subjek (S2) dapat dilihat pada gambar 4 dan gambar 5 sebagai berikut:

Cara pertama:

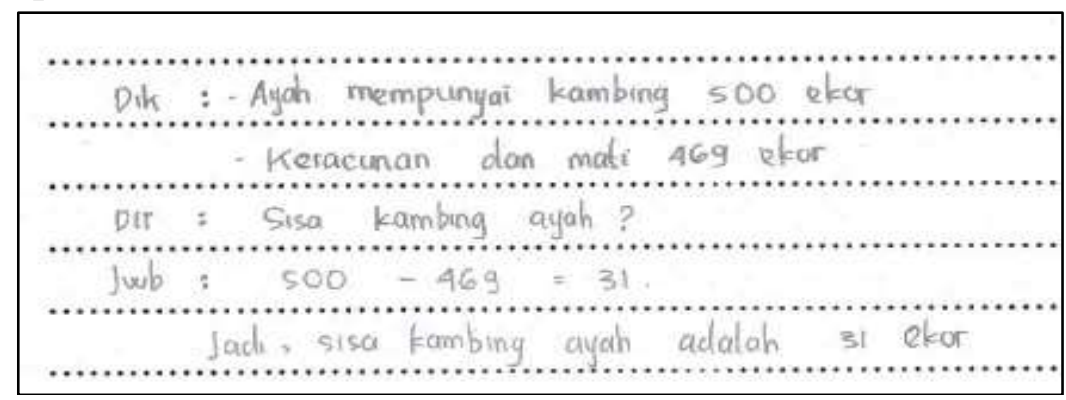

Gambar 4. Hasil Pekerjaan Subjek (S2) pada Cara Pertama

Berdasarkan wawancara yang dilakukan pada subyek S2 menunjukan bahwa S2 memahami masalah yang diberikan dan jawabannya "benar". Namun S2 hanya tidak mengunakan cara/model penyelesaian, S2 menggunakan representasi numerik dan menggunakan cara langsung "operasi pengurangan" dengan menghubungkan banyaknya kambing 500 ekor dengan banyaknya kambing 469 ekor yang mati. (dapat dilihat pada gambar 4)

Cara kedua:

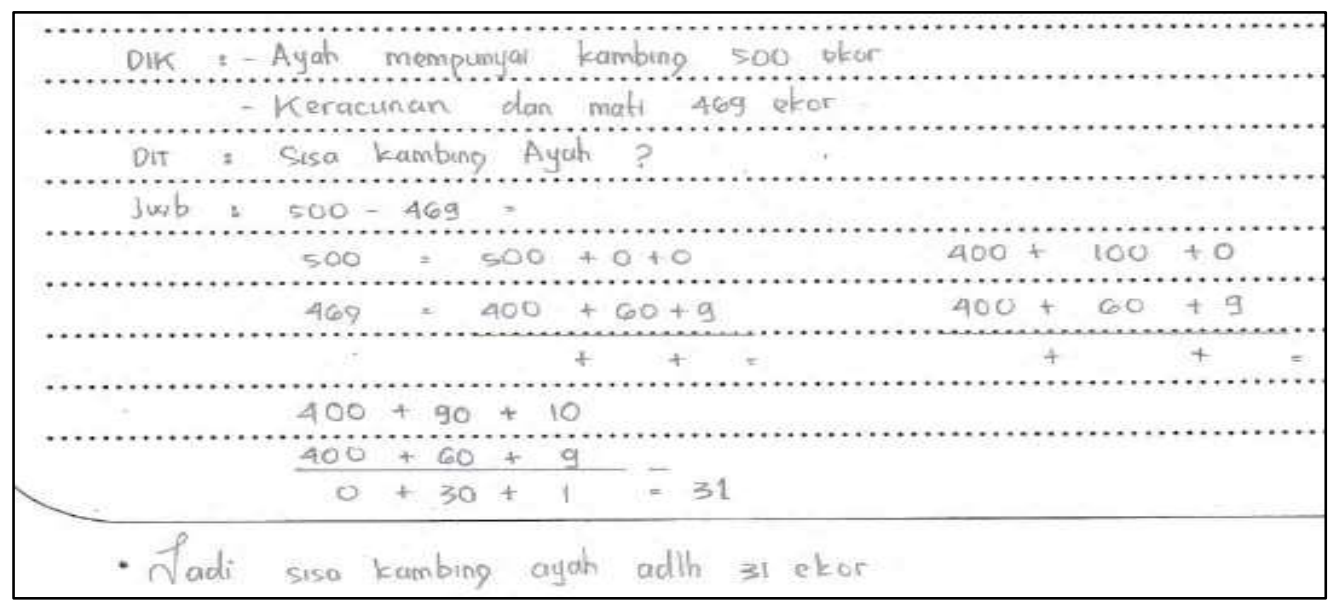

Gambar 5. Hasil Pekerjaan Subjek (S2) pada Cara Kedua 
Pada cara kedua ini (gambar 5), subjek S2 menyelesaikan soal yang diberikan menggunakan cara yang sama dengan subjek S1 yaitu menggunakan representasi numerik dengan menghubungkan banyaknya kambing 500 ekor dengan banyak kambing 469 yang mati dengan menggunakan operasi pengurangan, seperti menguraikan bilangan ratusan, puluhan, dan satuan.

Deskripsi hasil pekerjaan subjek (S3) dapat dilihat pada gambar 6 dan gambar 7 sebagai berikut.

Cara pertama:

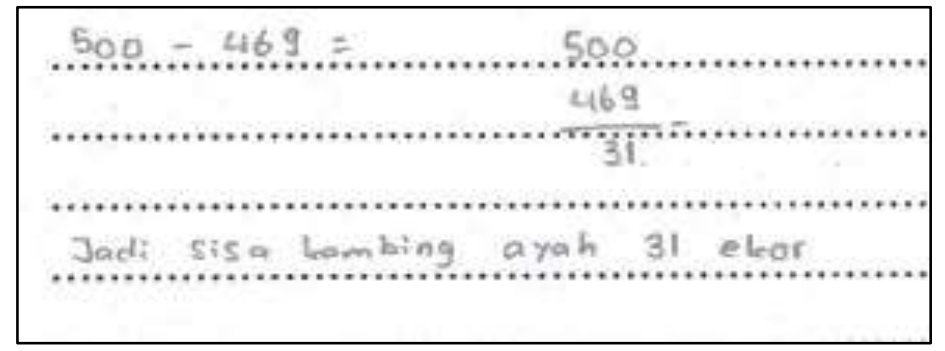

Gambar 6. Hasil Pekerjaan Subjek (S3) pada Cara Pertama

Berdasarkan wawancara dengan subyek S3 dalam menyelesaikan soal yang diberikan menunjukan bahwa S3 menggunakan cara "bersusun" (gambar 6). Tetapi S3 tidak menuliskan hal yang diketahui, ditanyakan, dan langsung melakukan proses penyelesaian dengan melakukan operasi pengurangan pada bilangan yang diberikan.

Cara kedua:

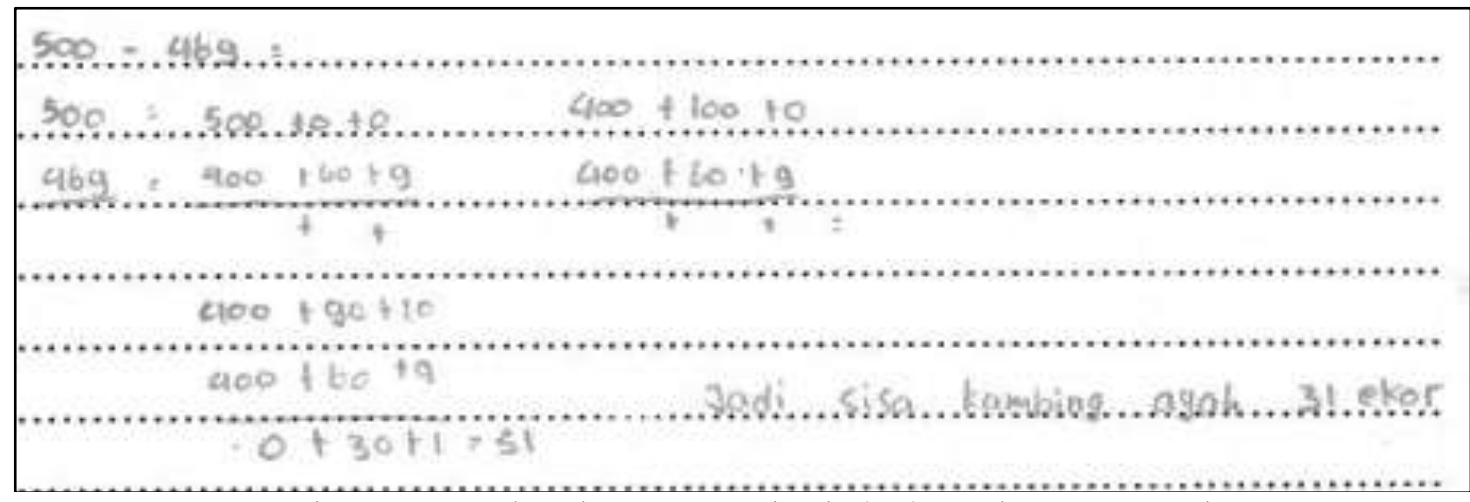

Gambar 7. Hasil Pekerjaan Subjek (S3) pada Cara Kedua

Pada cara kedua ini (gambar 7), subjek (S3) menyelesaikan soal yang diberikan sama dengan S1 dan S2 yaitu menguraikan operasi pengurangan dengan menguraikan bilangan ratusan, puluhan, dan satuan lalu dikurangkan. Namun S3 tidak menuliskan hal yang diketahui, ditanyakan, 
dan langsung pada proses penyelesaian. S3 juga banyak menggunakan angka dalam proses penyelesaian (representasi numerik) sama seperti yang dilakukan oleh S1 dan S2.

Dari 26 subjek yang diberikan soal cerita, hampir semua siswa menggunakan representasi numerik dan terdapat 3 macam karakteristik jawaban diantaranya adalah cara pertama S1 mengawalinya dengan menuliskan hal yang diketahui dan ditanyakan. Kemudian dalam proses penyelesaian S1 menggunakan metode "bersusun" dalam mengoperasikan pengurangan pada bilangan. Sedangkan pada cara kedua S1 juga menuliskan hal yang diketahui dan ditanyakan, namun pada proses penyelesaian S1 menguraikan operasi pengurangan dengan menguraikan bilangan ratusan, puluhan dan satuan lalu dikurangkan.

Pada cara pertama S2, juga menuliskan hal yang diketahui dan ditanyakan. Namun pada proses penyelesaian S2 tidak menuliskan metode apa yang digunakan, S2 langsung melakukan operasi pengurangan pada bilangan yang diberikan. Sedangkan pada cara kedua S2 juga melakukan hal sama dengan S1 yaitu menuliskan hal yang diketahui, ditanyakan, dan kemudian proses penyelesaian S2 menguraikan operasi pengurangan dengan menguraikan bilangan ratusan, puluhan, dan satuan lalu dikurangkan.

Cara pertama yang dilakukan S3 adalah tidak menuliskan hal yang diketahui, ditanyakan, dan langsung melakukan proses penyelesaian dengan melakukan operasi pengurangan pada bilangan. Sedangkan pada cara kedua S3 juga tidak menuliskan hal yang diketahui dan ditanyakan. Namun pada proses penyelesaian S3 melakukan hal yang sama dilakukan oleh S1 dan S2 yaitu menguraikan operasi pengurangan dengan menguraikan bilangan ratusan, puluhan, dan satuan lalu dikurangkan.

Berdasarkan temuan di atas, kebanyakan siswa menggunakan nomor/angka dalam proses penyelesaian dan tanpa mengkombinasikan dengan representasi yang lain. Penggunaan nomor/angka sangat penting dalam memperoleh pemahaman masalah dan menyelidiki kasus-kasus tertentu, maka representasi tersebut memiliki ciri-ciri utuh dari representasi numerik. Hal ini sejalan dengan pendapat Friedlander \& Tabach (2001) yang menyatakan bahwa representasi numerik adalah representasi yang sudah akrab dengan siswa di tahap awal belajar aljabar dan penggunaan nomor/angka penting dalam memperoleh pemahaman masalah dan menyelidiki kasus-kasus tertentu. Representasi numerik dipilih siswa, dikarenakan siswa cenderung meniru langkah-langkah guru dalam 
menyelesaikan masalah. Hal ini disebabkan karena guru belum memberikan alternatif-alternatif lain dalam menyelesaikan soal cerita. Padahal, representasi sangat berguna dalam pembelajaran matematika khususnya bagi siswa dan guru. Jika siswa dapat mengkombinasikan penggunaan representasi dalam menyelesaikan masalah dapat meminimalisir kelemahan-kelemahan dari masing-masing representasi. Hal ini sejalan dengan rekomendasi Kaput (1992) yang menyatakan bahwa mengkombinasikan penggunaan representasi dapat mengurangi kelemahan dan terbukti menjadi alat yang efektif.

\section{SIMPULAN}

Dalam proses penyelesaian soal cerita, terdapat beberapa langkahlangkah dan metode yang digunakan siswa. Langkah pertama, siswa menggunakan langkah-langkah penyelesaian soal cerita dengan memahami masalah, yakni menuliskan hal yang diketahui dan ditanyakan, merencanakan penyelesaian, dan melaksanakan penyelesaian. Pada tahap akhir siswa mengecek kembali, apakah hasil jawabannya benar. Hal ini sejalan dengan pendapat Polya (1957) yang menyatakan bahwa pemecahan masalah terdapat empat tahapan yaitu memamahi masalah, merencanakan pemecahan, melaksanakan rencana pemecahan, dan memeriksa kembali. Kedua, metode penyelesaian yang digunakan ada dua metode yaitu metode "bersusun" dan metode "penguraian" yaitu menguraikan puluhan, ratusan, dan satuan. Representasi yang digunakan siswa dalam proses menyelesaikan soal cerita adalah representasi numerik karena subyek S1, S2, dan S3 kebanyakan menggunakan angka. Hal ini dimungkinkan siswa cenderung meniru langkah-langkah guru dalam menyelesaikan masalah. Dengan demikian, representasi penyelesaian soal cerita siswa masih belum maksimal, maka hendaknya guru perlu merencanakan pembelajaran dan memfasilitasi kegiatan dalam proses pembelajaran dengan banyak memberikan latihanlatihan soal cerita sehingga siswa dapat terlatih dalam merepresentasikan penyelesaian soal cerita dengan representasi yang lain dan dapat mengkombinasikannya dengan representasi satu dengan yang lain.

\section{DAFTAR PUSTAKA}

BAL, A. P. (2014). The examination of representation used by classroom teacher candidate in solving mathematics problems. Educational Science Theory \& Practice, 14(6), 2349-2365. Retrieved from https:/ / files.eric.ed. gov/fulltext/EJ1050592.pdf. 
Cai, J., Jakabcsin, M. S., \& Lane, S. (1996). Assesing students mathematical communication. Science and Mathematics, 96(5), 238-246. Retrieved from https:// onlinelibrary.wiley.com/doi/abs/10.1111/j.1949-8594.1996.tb1 0235.x.

Chilmiyah, S. M. (2014). Kemampuan berpikir siswa dalam menyelesaikan soal cerita matematika. Jurnal Pendidikan Matematika STKIP PGRI Sidoarjo, 2(2), 237-247. Retrieved from http://lppm.stkippgrisidoarjo.ac.id/files/kemampuan-berpikir-siswa-dalam-menyelesaikansoal-cerita-matematika.pdf.

Delice, A., \& Sevimli, E. (2010). An investigation of the pre-service teacher's ability of using multiple representation in problem solving success: The Case of Definite Integral. Education Science \& Theory Practice, 10(1), 137149. Retrieved from https:/ / eric.ed.gov/?id=EJ882726.

Friedlander, A., \& Tabach, M. (2001). Promoting multiple representation in algebra. In Yearbook of the National Council of Teachers of mathematics (pp. 173-185). Reston, Virginia: The Council. Retrieved from https://www.researchgate.net/publication/240637608_promoting_mul tiple_representations_in_algebra.

Gerjets, P., Scheiter, K., \& Catrambone, R. (2004). Designing instructional examples to reduce intrinsic cognitive load: Molar versus modular presentation of solution procedures. Instructional Science, 32(1-2), 33-58. Retrieved from https:/ /link.springer.com/article/10.1023/B:TRUC.000 0021809.10236.71.

Goldin, G. A. (2002). Perspective on representation in mathematical learning and problem solving. In Handbook of International Research in Mathematics Education (2nd Ed.) (pp. 176-201).

Hwang, W. Y., Chen, N. S., Dung, J. J., \& Yang, Y. L. (2007). Multiple representation skills and creativity effects on mathematical problem solving using a multimedia whiteboard system. Educational Technology and Science, 10(2), 191-212. Retrieved from https:/ / pdfs.semanticscholar .org/d6bb/9c4f430c46a4123bee35b6f33b4922ecaddc.pdf.

Jones, B. F., \& Knuth, R. A. (1991). What does research say about mathematics? Retrieved from http://www.ncrl.org/sdrs/stwesys/2math.html

Kaput, J. J. (1992). Techology and mathematics education. In D. A. Grouws (Ed.), Handbook of Research on Mathematics Teaching and Learning. New York.

Koedinger, K. R., \& Nathan, M. J. (2004). The real story behind story problems: Effects of representations on quantitative reasoning. The Journal of the Learning Sciences, 13(2), 129-164. Retrieved from https://www.tandfonli ne.com/doi/abs/10.1207/s15327809jls1302_1.

Mielicki, M., \& Willey, J. (2016). Alternative representations for algebraic problem solving: When are graphs better than equations? The Journal of 
Problem Solving, 9(1), 3-12. Retrieved from https:/ / docs.lib.purdue.edu /jps/vol9/iss1/1/.

NCTM. (2000). Principle and Standards for School Mathematics. Reston, VA: NCTM.

Ozgun-Koca, S. A. (1998). Student's use representation in mathematics education. In Paper Presented at the Annual Meeting of the North American Chapter of the International Group for the Psychology of Mathematics Education (pp. 1-16). Retrieved from https:/ / eric.ed.gov/?id=ED425937

Polya, G. (1957). How to solve it (2nd ed.). Princeton: Princeton University Press.

Scheiter, K., Gerjets, P., \& Schuh, J. (2010). The acquisition of problem-solving skills in mathematics: How animations can aid understanding of structural problem features and solution procedures. Instructional Science, 38(5), 487-502. Retrieved from https:/ /link.springer.com/articl e/10.1007/s11251-009-9114-9.

Surya, E., Sabandar, J., Kusumah, Y. S., \& Darhim. (2013). Improving of junior high school visual thingking representation ability in mathematical problem solving by CTL. IndoMS J.M.E, 4(1), 113-126. Retrieved from https:/ / files.eric.ed.gov/fulltext/ EJ1078960.pdf.

Tambunan, H. (1999). Kemampuan siswa menyelesaikan soal cerita pokok bahasan trigonometri dengan strategi heuristik. PPs UNESA. 